\title{
Research on the Training Objective of Traffic and Transportation Specialty (rail traffic operation management) Based on Analytic Hierarchy Process
}

\author{
Jing Sheng*, Chen-chen Zhang, Xue-mei Xiao, Jia-wei Zheng \\ ${ }^{1}$ School of mechanical and automotive engineering, Xiamen University of Technology \\ Xiamen, Fujian, P.R. of China, 361024
}

\begin{abstract}
To continually optimize the personnel training program, it is significant to properly assess the conformance of both the standard and the purpose of personnel training. We proceed from the personnel training program of traffic transportation majority in our school and point out the AHPbased fuzzy evaluation method aiming at the assessment of personnel training objective. Through analyzing the hierarchy of from training objective to curriculum system, the judgment matrix of criterion layer (graduation requirement) and index level (knowledge, ability and quality) is established, thus determining the corresponding weight; on the basis of establishing the fuzzy relation matrix of the criterion layer term by term, the fuzzy relation matrix of the training objective is constructed. The fuzzy comprehensive evaluation method is used to assess the personnel training objective. The assessment results show that the goal of cultivating talents is 'excellent', which means the training goal is consistent with the training standard. This study provides a theoretical basis and practical guidance for the development of personnel training standards.
\end{abstract}

Keywords-Transportation major; Talent training target; Training standard; Analytic hierarchy process; Evaluation method

\section{INTRODUCTION}

With the globalization of economy, the internationalization of education becomes inevitable. In 2016, China became a member of the Washington Agreement, and initially established the accreditation system of engineering education which is in line with the requirements of the Washington Agreement [1]. As everyone knows, talent training program is an important basis to ensure the quality of engineering education and achieve the goal of personnel training. It is the basic to organize teaching process, assign teaching tasks and so on [2]. But graduation requirements are the training standards or specifications of personnel training. Therefore, Graduation requirement is the pillar of constructing training target.

How to evaluate the consistency between graduation requirements and training goals has become a key issue in talent training program formulation. Zhao Yafu [3] analyzed the relationship between personality training objectives and evaluation objectives, and studied the method of personality target evaluation and measurement. Xiang Xinghua [4] aims at the target orientation and performance evaluation of talent training in Colleges and Universities, and studies the index

[Fund Project] Educational Reform \& Construction Project of Xiamen University of Technology (JGZ201501) and Xiamen Education Science "12th Five-Year" Project (1528).

[Profile] Sheng Jing (1965-, male), Hubei, Wuchang. Professor, Ph. D., Research interests: intelligent manufacturing and computer integrated manufacturing technology. system and weight determination method of university orientation evaluation. And he carries on the positive analysis, puts forward the target orientation and Countermeasures of talent training in Colleges and Universities. Zha Jianzhong [5] constructs the macro control model of engineering education system by using the idea of cybernetics, and discusses the training target and evaluation system of engineering education. Wang Shiyong [6] analyzes several key problems of evaluating graduation requirements, and puts forward the calculation method and evaluation of graduation requirements, and makes an empirical study.

These studies have evaluated training objectives from several perspectives. However, the research on the evaluation of training objectives has not been reported yet. This study is directed to the major of transportation in our school (Rail traffic operation management). According to the training program of engineering education professional certification standards, this paper explores an evaluation method based on graduation requirements, and provides theoretical basis and practical guidance for the formulation of talent training programs.

\section{RESEARCH METHOD}

The strategic goal of training talents in universities will be transformed into operational personnel training targets through layers of decomposition and then it will be transformed into specific training standards. In the general standard of engineering education accreditation, the corresponding training goal needs 12 graduation requirements to realize, and each graduation request has each index item to support. Therefore, the training objective is guaranteed by a hierarchy index system.

\section{A. Determination of weights}

To evaluate the above index system, the weight value of each index is the main consideration. Methods commonly used to determine the weight of indicators are:

Subjective weighting method, objective weighting method and combination weighting method. The architecture based on training objectives is hierarchical, and [7] Analytic Hierarchy Process can be used. In view of the characteristics of this study, Analytic Hierarchy Process and subjective weighting method are used to determine the weight values. 


\section{B. Evaluation methodology}

Because the evaluation factors are difficult to describe quantitatively, and Because of the hierarchy of evaluation object and the fuzziness of evaluation criterion, it makes the evaluation of training target difficult to express the result accurately. Therefore, This study intends to apply the comprehensive evaluation method based on Fuzzy Theory. In this way, we can aim at the hierarchical characteristics of the evaluation object, and reflect the fuzziness of the evaluation criteria and the influencing factors. Moreover, it can bring people's subjective initiative into full play and make the evaluation result accord with the objective.

\section{Analysis of evaluation results}

The processing methods of evaluation results are as follows: weighted average principle, fuzzy vector single value and maximum membership principle. The evaluation result needs to be chosen according to the evaluation result.

\section{EVALUATION CRITERIA AND WEIGHTS OF TRAINING}

OBJECTIVES FOR RAIL TRANSPORTATION SPECIALTY (RAIL TRAFFIC OPERATION MANAGEMENT)

\section{A. Evaluation criteria for training target of rail transportation specialty (Rail traffic operation management)}

According to the national engineering education professional certification standards, combined with the transportation professional standards, based on our school positioning and Professional training objective, the training standard of the major has been drawn up and formed its evaluation criteria. See Table 1 (limited to space and listed only partially).

TABLE I. TRAINING STANDARDS FOR TRANSPORTATION SPECIALTY (RAIL TRAFFIC OPERATION MANAGEMENT)

\begin{tabular}{|c|c|c|}
\hline $\begin{array}{c}\text { Graduation } \\
\text { requirements }\end{array}$ & Knowledge, ability and quality & A link or path of realization \\
\hline \multirow{4}{*}{$\begin{array}{l}\text { 1. Engineering } \\
\text { knowledge: The } \\
\text { ability to apply } \\
\text { mathematics, } \\
\text { natural science, } \\
\text { engineering, and } \\
\text { expertise to } \\
\text { solve complex } \\
\text { engineering } \\
\text { problems in } \\
\text { Transportation } \\
\text { Engineering }\end{array}$} & $\begin{array}{c}\text { Have a solid knowledge of } \\
\text { mathematics and other related } \\
\text { natural sciences. }\end{array}$ & $\begin{array}{l}\text { Advanced Mathematics I, college } \\
\text { physics, I (I), college physics, I (II), } \\
\text { Linear Algebra I, probability theory and } \\
\text { mathematical statistics, I, statistics }\end{array}$ \\
\hline & $\begin{array}{l}\text { Knowledge of mechanics, } \\
\text { electrotechnics and electronics. }\end{array}$ & $\begin{array}{l}\text { Engineering Mechanics I, electrical and } \\
\text { electronic technology, electrical and } \\
\text { electronic integrated practice }\end{array}$ \\
\hline & $\begin{array}{l}\text { Grasp the basic theories and } \\
\text { knowledge of operations research, } \\
\text { management, transportation, } \\
\text { organization, etc. }\end{array}$ & $\begin{array}{l}\text { Operations research, management } \\
\text { principles, management information } \\
\text { systems, transportation organizations, } \\
\text { transportation planning theories and } \\
\text { methods }\end{array}$ \\
\hline & $\begin{array}{l}\text { Learn how to analyze and solve } \\
\text { problems by computer, and master } \\
\text { the basic methods of programming }\end{array}$ & $\begin{array}{c}\text { Computer application technology } \\
\text { foundation II, C Language } \\
\text { Programming II, VFP database } \\
\text { program design }\end{array}$ \\
\hline$\equiv$ & $\sum$ & $\vdots$ \\
\hline \multirow{2}{*}{$\begin{array}{l}\text { 12. Lifelong } \\
\text { learning: self- } \\
\text { learning and } \\
\text { lifelong learning } \\
\text { consciousness, } \\
\text { have the ability } \\
\text { to learn and } \\
\text { adapt to } \\
\text { development. }\end{array}$} & $\begin{array}{l}\text { Train students to acquire } \\
\text { information, information and } \\
\text { ability to keep track of the latest } \\
\text { technological trends in the field by } \\
\text { means of various means. }\end{array}$ & $\begin{array}{l}\text { Computer course design, course design } \\
\text { of urban rail driving organization, } \\
\text { curriculum design of passenger } \\
\text { entrance and exit organization design, } \\
\text { curriculum design and graduation } \\
\text { design of urban rail transit safety and } \\
\text { emergency design }\end{array}$ \\
\hline & & \\
\hline
\end{tabular}




\section{B. Construction of weights of analytic hierarchy process}

1) Establish a hierarchical structure model of professional training objectives

According to the analytic hierarchy process (AHP), [7] can divide the hierarchical structure of professional training objectives into three layers: the highest level (target layer), the middle layer (criterion layer) and the bottom (indicator layer). Among them, the target layer is a comprehensive evaluation of transportation (A); the standard layer is the graduation requirements of Xiamen University of Technology (Ti); the target level are knowledge, ability and quality indicators (Cij). Among them, the intermediate layer has $\mathrm{T} 1$ : engineering knowledge: it is able to solve the complex engineering problems of traffic engineering with mathematics, natural science, engineering basis and professional knowledge;T2: problem analysis (able to apply the basic principles of mathematics, natural science and Engineering Science, to identify, express, and analyze complex engineering problems of transportation engineering through literature studies) to obtain valid conclusions; $\cdots \cdots$, T12: lifelong learning (autonomous learning and lifelong learning), the ability to learn and adapt to development.

\section{2) Construct different levels of judgment matrix}

(1) Select 12 graduation requirements and establish a judgment matrix,

$$
A=\left[\begin{array}{cccccc}
T & T_{1} & T_{2} & \cdots & T_{11} & T_{12} \\
T_{1} & 1 & 1 / 2 & \cdots & 1 / 3 & 1 \\
T_{2} & 2 & 1 & \cdots & 1 / 2 & 2 \\
\vdots & \vdots & \vdots & \ddots & \vdots & \vdots \\
T_{11} & 3 & 2 & \cdots & 1 & 2 \\
T_{12} & 1 & 1 / 2 & \cdots & 1 / 2 & 1
\end{array}\right]
$$

(2)The comparison matrix of the bottom layer with respect to the criterion layer is as follows:

$$
\begin{aligned}
B_{1} & =\left[\begin{array}{ccccc}
C_{1} & C_{11} & C_{12} & C_{13} & C_{14} \\
C_{11} & 1 & 2 & 2 & 1 / 2 \\
C_{12} & 1 / 2 & 1 & 1 & 1 / 4 \\
C_{13} & 1 / 2 & 1 & 1 & 1 / 4 \\
C_{14} & 2 & 4 & 4 & 1
\end{array}\right] \\
\vdots &
\end{aligned}
$$

\section{Determine weight}

Each judgment comparison matrix is solved by the method of square root, and the relative weight of each criterion and its index level is obtained.

(1) Criterion layer mutual comparison judgment matrix A is solved

Weight vector of criterion layer

$$
w_{i}=\sqrt[n]{\prod_{j}^{n} r_{i j}} / \sum_{j=1}^{n} \sqrt[n]{\prod_{j}^{n} r_{i j}} \quad i=1,2, \ldots, 12
$$

$w_{A}=\left(w_{1}, w_{2}, \cdots \cdots, w_{12}\right)^{T}=(0.0305,0.0565, \cdots \cdots, 0.0379)^{T}$

Maximum eigenvalue : $\lambda_{A \max }=\sum_{j}^{n} \frac{(B W)_{i}}{n w_{i}}=12.6693$

Consistency test: $C I=\frac{\lambda_{\max }-n}{n-1}=\frac{12.6693-12}{12-1}=0.0608$

Within the range allowed by the error, you can check it directly through the RI table, as shown in Table 2 below.

TABLE II. RI VALUE LIST

\begin{tabular}{|l|l|l|l|l|l|l|l|l|l|}
\hline Order & 1 & 2 & 3 & 4 & 5 & 6 & 7 & 8 & 9 \\
\hline$R I$ & 0.00 & 0.00 & 0.58 & 0.90 & 1.21 & 1.24 & 1.32 & 1.41 & 1.25 \\
\hline
\end{tabular}

Select the maximum value of the index layer of training standard $n=7$, judge the establishment of the matrix $R I=1.32$, and calculate the consistency ratio $\mathrm{CR}$ :

$$
C R=C I / R I=0.0461<0.1
$$

(2)The judgment of the index layer is compared with the solution of the matrix $B$

Weight vector of index layer:

$$
\begin{aligned}
& w_{1}=(0.2442,0.1221,0.1452,0.4884) \\
& w_{2}=(0.1327,0.3788,0.2340,0.1327,0.0753,0.0465) \\
& \vdots \\
& w_{12}=(0.4531,0.1602,0.1602,0.2265) \\
& \quad \text { Maximum eigenvalue: } \\
& \lambda_{C 1 \max }=\sum_{j}^{n} \frac{(B W)_{i}}{n w_{i}}=4.2330 \\
& \lambda_{C 2 \max }=\sum_{j}^{n} \frac{(B W)_{i}}{n w_{i}}=6.0431 \\
& \vdots \\
& \lambda_{C 12 \max }=\sum_{j}^{n} \frac{(B W)_{i}}{n w_{i}}=4.2464
\end{aligned}
$$


Consistency test:

$$
\begin{gathered}
C I_{C 1}=\frac{\lambda_{C 1 \max }-n}{n-1}=0.0777, R I=1.32, C R_{C 1}=C I_{C 1} / R I=0.0588<0.1 \\
C I_{C 2}=\frac{\lambda_{C 2 \max }-n}{n-1}=0.0086, R I=1.32, C R_{C 2}=C I_{C 2} / R I=0.0065<0.1
\end{gathered}
$$

$$
C I_{C 12}=\frac{\lambda_{C 12 \max }-n}{n-1}=0.0821, R I=1.32, C R_{C 12}=C I_{C 12} / R I=0.0622<0.1
$$

The above calculation results show that the judgment matrix of the index layer meets the consistency requirements.

Based on the above calculation results, the weights of each criterion layer and its index level are obtained for training standards of transportation major (see Table 3).

\begin{tabular}{|c|c|c|c|}
\hline $\begin{array}{l}\text { Criterion } \\
\text { layer }\end{array}$ & $\begin{array}{l}\text { Criterion } \\
\text { weight }\end{array}$ & Index layer & $\begin{array}{c}\text { Index } \\
\text { weight }\end{array}$ \\
\hline \multirow{6}{*}{$\begin{array}{l}\text { T1: } \\
\text { Engineering } \\
\text { knowledge }\end{array}$} & \multirow[t]{6}{*}{0.0305} & $\begin{array}{l}\text { C11: Have a solid knowledge of mathematics } \\
\text { and other related natural sciences }\end{array}$ & 0.2442 \\
\hline & & $\begin{array}{l}\text { C12: Knowledge of mechanics, } \\
\text { electrotechnics and electronics }\end{array}$ & 0.1221 \\
\hline & & $\begin{array}{l}\text { C13: Grasp the basic theories and knowledge } \\
\text { of operations research, management, } \\
\text { transportation, organization, etc. }\end{array}$ & 0.1452 \\
\hline & & $\begin{array}{l}\text { C14: Learn how to analyze and solve } \\
\text { problems by computer, and master the basic } \\
\text { methods of programming }\end{array}$ & 0.4884 \\
\hline & & $\begin{array}{l}\text { C11: The basic concepts of mathematics and } \\
\text { natural science can be applied to the } \\
\text { formulation of engineering problems } \\
\text { (systems or processes), and the correct } \\
\text { mathematical models can be established }\end{array}$ & 0.1327 \\
\hline & & $\begin{array}{l}\text { C12: Using mathematics and other related } \\
\text { natural science theories and methods to } \\
\text { analyze and solve engineering practice } \\
\text { problems }\end{array}$ & 0.3788 \\
\hline$\equiv$ & $\equiv$ & $\equiv$ & $\equiv$ \\
\hline \multirow[t]{4}{*}{$\begin{array}{l}\text { T12: } \\
\text { Lifelong } \\
\text { learning }\end{array}$} & \multirow[t]{4}{*}{0.0379} & $\begin{array}{l}\text { C11: Train students to acquire information, } \\
\text { information and ability to keep track of the } \\
\text { latest technological trends in the field by } \\
\text { means of various means }\end{array}$ & 0.4531 \\
\hline & & $\begin{array}{l}\text { C12: Ability to continually review their own } \\
\text { development needs and to develop and } \\
\text { implement a continuing learning program }\end{array}$ & 0.1602 \\
\hline & & $\begin{array}{l}\text { C13: The ability to expand knowledge and } \\
\text { continue learning }\end{array}$ & 0.1602 \\
\hline & & C14: Have good physical and mental quality & 0.2265 \\
\hline
\end{tabular}

$\vdots$

TABLE III. WEIGHT OF EACH PERFORMANCE EVALUATION SYSTEM OF TRANSPORTATION SPECIALTY (RAIL TRAFFIC OPERATION MANAGEMENT)

\section{FUZZY COMPREHENSIVE EVALUATION}

The fuzzy comprehensive evaluation method can comprehensively evaluate the indexes of the subject, and comprehensively reflect the degree of excellence of the object being evaluated. Therefore, in this study, fuzzy comprehensive evaluation method is adopted to analyze the performance of training standards. And the graduation requirements of the training target are evaluated. 


\section{A. Construct factor set $U$}

Establish graduation requirement sets from training standards: $\mathrm{U}(\mathrm{A})=\{\mathrm{T} 1, \mathrm{~T} 2, \cdots, \mathrm{T} 12\}$, index set: $\mathrm{U}(\mathrm{C} 1)=$ $\{\mathrm{C} 11, \mathrm{C} 12, \cdots, \mathrm{C} 17\}(\mathrm{i}=1,2, \cdots, 12)$.

\section{B. Determine the evaluation set $V$}

Apply the five grade scoring system to evaluate the graduation requirements and the training goal of the major, Evaluation set : $\mathrm{V}=\{$ Excellent, good, medium, low, poor $\}$.

\section{Establish evaluation index weight}

By using analytic hierarchy process (AHP), the weights of performance evaluation system are obtained (see Table 4). Index (knowledge, ability and quality) and the weight of each performance evaluation system are obtained (see Table 5).

TABLE IV. GRADUATION REQUIRES THE WEIGHT OF EACH PERFORMANCE EVALUATION SYSTEM

\begin{tabular}{|c|c|c|c|c|c|c|c|}
\hline $\begin{array}{c}\text { Index } \\
\text { item }\end{array}$ & $\begin{array}{c}\text { Weight } \\
\text { value }\end{array}$ & $\begin{array}{c}\text { Index } \\
\text { item }\end{array}$ & $\begin{array}{c}\text { Weight } \\
\text { value }\end{array}$ & $\begin{array}{c}\text { Index } \\
\text { item }\end{array}$ & $\begin{array}{c}\text { Weight } \\
\text { value }\end{array}$ & $\begin{array}{c}\text { Index } \\
\text { item }\end{array}$ & $\begin{array}{c}\text { Weight } \\
\text { value }\end{array}$ \\
\hline $\mathrm{T} 1$ & 0.0305 & $\mathrm{~T} 2$ & 0.0565 & $\mathrm{~T} 3$ & 0.0678 & $\mathrm{~T} 4$ & 0.1878 \\
\hline $\mathrm{T} 5$ & 0.1077 & $\mathrm{~T} 6$ & 0.0305 & $\mathrm{~T} 7$ & 0.0305 & $\mathrm{~T} 8$ & 0.0634 \\
\hline $\mathrm{T} 9$ & 0.1208 & $\mathrm{~T} 10$ & 0.1878 & $\mathrm{~T} 11$ & 0.0787 & $\mathrm{~T} 12$ & 0.0379 \\
\hline
\end{tabular}

TABLE V. WEIGHT OF INDEXES (KNOWLEDGE, ABILITY AND QUALITY) AND PERFORMANCE EVALUATION SYSTEM

\begin{tabular}{|c|c|c|c|c|c|c|c|}
\hline $\begin{array}{c}\text { Graduation } \\
\text { requirement serial } \\
\text { number } / i\end{array}$ & $C_{i 1}$ & $C_{i 2}$ & $C_{i 3}$ & $C_{i 4}$ & $C_{i 5}$ & $C_{i 6}$ & $C_{i 7}$ \\
\hline 1 & 0.2442 & 0.1221 & 0.1452 & 0.4884 & 0.0000 & 0.0000 & 0.0000 \\
\hline 2 & 0.1327 & 0.3788 & 0.2340 & 0.1327 & 0.0753 & 0.0465 & 0.0000 \\
\hline 3 & 0.0823 & 0.0823 & 0.1580 & 0.0823 & 0.2793 & 0.1580 & 0.1580 \\
\hline 4 & 0.1240 & 0.1240 & 0.1240 & 0.2341 & 0.3940 & 0.0000 & 0.0000 \\
\hline 5 & 0.1094 & 0.2065 & 0.1094 & 0.3682 & 0.2065 & 0.0000 & 0.0000 \\
\hline 6 & 0.1429 & 0.1429 & 0.1429 & 0.2857 & 0.2857 & 0.0000 & 0.0000 \\
\hline 7 & 0.2000 & 0.6000 & 0.2000 & 0.0000 & 0.0000 & 0.0000 & 0.0000 \\
\hline 8 & 0.1859 & 0.1859 & 0.4422 & 0.1859 & 0.0000 & 0.0000 & 0.0000 \\
\hline 9 & 0.4000 & 0.2000 & 0.4000 & 0.0000 & 0.0000 & 0.0000 & 0.0000 \\
\hline 10 & 0.0953 & 0.1603 & 0.2776 & 0.4668 & 0.0000 & 0.0000 & 0.0000 \\
\hline 11 & 0.1411 & 0.1411 & 0.2627 & 0.4550 & 0.0000 & 0.0000 & 0.0000 \\
\hline 12 & 0.4531 & 0.1602 & 0.1602 & 0.2265 & 0.0000 & 0.0000 & 0.0000 \\
\hline
\end{tabular}

\section{Establish fuzzy relation matrix}

1) Construct the evaluation matrix of graduation requirements
According to the specific conditions of the training standard index, the membership function of the corresponding item is constructed. Through the questionnaire survey of experts and scholars, get an expert score. Table 6 is the grading of each item in the first item of the training standard.

TABLE VI. EXPERT SCORING TABLE

\begin{tabular}{|ccccccc|}
\hline Graduation & Knowledge, ability and & \multicolumn{2}{c}{ order of evaluation } \\
requirements & quality code & Excellent & good & middle & low & bad \\
& & & & & & \\
\hline Engineering & C11 $(0.2442)$ & 0.70 & 0.20 & 0.10 & 0.00 & 0.00 \\
& C12(0.1211) & 0.70 & 0.30 & 0.00 & 0.00 & 0.00 \\
knowledge & C13(0.1452) & 0.60 & 0.20 & 0.20 & 0.00 & 0.00 \\
& C14(0.4884) & 0.80 & 0.10 & 0.10 & 0.00 & 0.00 \\
& C15(0.0000) & 0.00 & 0.00 & 0.00 & 0.00 & 0.00 \\
& C16(0.0000) & 0.00 & 0.00 & 0.00 & 0.00 & 0.00 \\
& C17(0.0000) & 0.00 & 0.00 & 0.00 & 0.00 & 0.00 \\
\hline
\end{tabular}


The fuzzy matrix R1 of each index item of the training standard can be established by table 6 .

$$
R_{1}=\left[\begin{array}{ccccc}
0.70 & 0.20 & 0.10 & 0 & 0 \\
0.70 & 0.30 & 0 & 0 & 0 \\
0.60 & 0.20 & 0.20 & 0 & 0 \\
0.80 & 0.10 & 0.10 & 0 & 0 \\
0 & 0 & 0 & 0 & 0 \\
0 & 0 & 0 & 0 & 0 \\
0 & 0 & 0 & 0 & 0
\end{array}\right]
$$

The evaluation index of "engineering knowledge" in the training standard is calculated as follows :

$B_{1}=W_{1} \circ R_{1}=\left[w_{11}, w_{12}, \cdots, w_{1 i}\right] \circ\left[\begin{array}{ccccc}r_{11} & r_{12} & r_{13} & \cdots & r_{1 j} \\ r_{21} & r_{22} & r_{23} & \cdots & r_{2 j} \\ r_{31} & r_{32} & r_{33} & \cdots & r_{3 j} \\ \vdots & \vdots & \vdots & \vdots & \vdots \\ r_{i 1} & r_{i 2} & r_{i 3} & \cdots & r_{i j}\end{array}\right](2)$

$=\left[\begin{array}{lllllll}0.2442 & 0.1221 & 0.1452 & 0.4884 & 0 & 0 & 0\end{array}\right] \circ\left[\begin{array}{ccccc}0.70 & 0.20 & 0.10 & 0 & 0 \\ 0.70 & 0.30 & 0 & 0 & 0 \\ 0.60 & 0.20 & 0.20 & 0 & 0 \\ 0.80 & 0.10 & 0.10 & 0 & 0 \\ 0 & 0 & 0 & 0 & 0 \\ 0 & 0 & 0 & 0 & 0 \\ 0 & 0 & 0 & 0 & 0\end{array}\right]$

$$
=\left[\begin{array}{llllllll}
0.0743 & 0.16324 & 0.1023 & 0 & 0 & 0 & 0
\end{array}\right]
$$

$\mathrm{B} 1$ is the result of the evaluation of "engineering knowledge". With the above steps and methods, you can get the evaluation matrix of other graduation requirements B2-B12.

\section{2) Establish training target evaluation matrix}

Because the evaluation level is divided into "excellent", "good", "medium", "low" and "bad", and the above obtained $\mathrm{B} 1=\left[\begin{array}{lll}0.7343, & 0.16324,0.1023,0,0,0.0000,0.0000\end{array}\right], 7$. According to the actual fuzzy relation matrix $\mathrm{R}(12 \times 5)$, the first 5 items of $\mathrm{B} 1$ are desirable, that is, [0.7343 0.16324 , $0.1023,0$ 0.0000]. The same treatment is done by B2-B12, and the training target evaluation matrix $\mathrm{R}$ is :

$$
R=\left[\begin{array}{lllll}
0.7343 & 0.1634 & 0.1023 & 0.0000 & 0.0000 \\
0.8245 & 0.1397 & 0.0312 & 0.0047 & 0.0000 \\
0.7050 & 0.2431 & 0.0520 & 0.0000 & 0.0000 \\
0.7234 & 0.1876 & 0.0890 & 0.0000 & 0.0000 \\
0.7304 & 0.1806 & 0.0891 & 0.0000 & 0.0000 \\
0.7000 & 0.2000 & 0.1000 & 0.0000 & 0.0000 \\
0.7000 & 0.2000 & 0.1000 & 0.0000 & 0.0000 \\
0.6558 & 0.2442 & 0.1000 & 0.0000 & 0.0000 \\
0.8200 & 0.0600 & 0.1000 & 0.0000 & 0.0000 \\
0.6840 & 0.2160 & 0.1000 & 0.0000 & 0.0000 \\
0.8192 & 0.1212 & 0.0596 & 0.0000 & 0.0000 \\
0.7066 & 0.2000 & 0.0934 & 0.0000 & 0.0000
\end{array}\right]
$$

\section{E. Fuzzy evaluation of training objectives}

Graduation requires that the weight of each is :

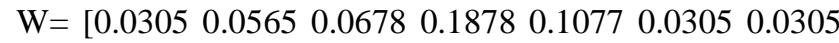
$0.06340 .12080 .18780 .07870 .0379]$

The evaluation results of training objectives can be obtained according to the following formula:

$$
B=W \circ R
$$

In the formula, $\mathrm{W}$ is the weight, and $\mathrm{R}$ is the fuzzy evaluation matrix.

$$
\mathrm{B}=\left[\begin{array}{lll}
0.73430 .17670 .08620 .00030
\end{array}\right]
$$

\section{F. Analysis of evaluation result}

Since this research is aimed at training standards of transportation major, the evaluation value is very different in the evaluation of training objectives, especially in the evaluation results, therefore, the principle of maximum membership degree is more applicable. The result shows that the maximum value of $B$ is 0.7343 , so it can be judged that the corresponding rating is excellent".

\section{CONCLUSION}

This study focuses on the major of transportation (rail traffic management) and studies the evaluation method in the light of the problem of whether the training standard meets the training goal. Take the pilot training standard of transportation professionals as an example, the analytic hierarchy process (AHP) is adopted to determine the weights of graduation design and its index levels in training standards; Through the establishment of fuzzy matrix and the use of fuzzy method to evaluate the training target, the result shows that the evaluation of talent training standard is "excellent", that is to say, it conforms to the target of talent training. This research provides an evaluation method for the design of personnel training standards in talent training program so as to provide a means for the optimization of talent training program. It also lays the foundation for the training of qualified professionals in transportation 


\section{REFERENCES}

[1] Wu Zhongjiang, Huang Chengliang. Connotation of applied talents and training of applied undergraduates. [J]. higher engineering education research, 2014 (2): 66-70.

[2] Li Zhiyi. Analysis of the concept of achievement oriented certification in engineering education. [J]. higher education of China, 2014 (17): 7-10.

[3] Zhao Yafu. General principles for setting up the objectives and evaluation methods of personality training in history subject $[\mathrm{J}]$. Journal of Capital Normal University (SOCIAL SCIENCE EDITION), 2002 (6): 106-111.

[4] Xiang Xinghua, Li Guochao, Zhao Qingnian. Research on the target orientation and performance evaluation of talent training in Colleges and
Universities -- taking two universities such as HL and HK for example, [J]. educational development research, 2014 (1): 23-30.

[5] Macro control model of engineering education and training objectives and educational evaluation $[\mathrm{J}]$. higher engineering education research, 2009 (3): 7-14.

[6] Wang Shiyong, Dong Wei, Zheng Junsheng, et al. Research and practice of graduation degree evaluation method for graduates based on accreditation standards of engineering education $[\mathrm{J}]$. industry and information education, 2016 (3): 15-22 [7] T L Saaty. The analytic Hierarchy Process: planning, Priority Setting, Resource Allocation [M]. New York : Mc Graw Hill. 1980.

[7] T L Saaty. The analytic Hierarchy Process: planning, Priority Setting, Resource Allocation [M]. New York : Mc Graw Hill. 1980. 